\title{
THREE SPECIES OF MONHYSTERIDS (NEMATODA, MONHYSTERIDA) FROM MANGROVE FOREST OF THE ME KONG RIVER ESTUARY, VIETNAM
}

\author{
NGUYEN VU THANH \\ Institute of Ecology and Biological Resources, VAST \\ VLADIMIR G. GAGARIN \\ Institute of Inland Waters Biology of Russian Academy of Sciences, Russia
}

\begin{abstract}
Three new free-living nematode species of the order Monhysterida from Me Kong river estuaries of Vietnam are described. Daptonema brevisetosum sp. nov. resembles to Daptonema setosum (Bütschli, 1874), but differs from it by the relatively shorter outer labial setae, shorter spicules and shorter cervical and somatic setae. Subsphaerolaimus major sp. nov. similar to Subsphaerolaimus lamasus (Gerlach, 1956), Subsphaerolaimus gerlachi (Wieser, 1959) and Subsphaerolaimus litoralis Lorenzen, 1978 , but differs from them by the longer body, longer spicules and presence of dorso-caudal apophysis of gubernaculum. Daptonema hirtum (Gerlach, 1957) is restored from synonymy of Daptonema setosum (Bütschli, 1874) and it is raised to range of valid species.
\end{abstract}

Key words: Free-living nematodes, new species, Me Kong river estuary, mangrove, Vietnam.

Fauna of free-living brackish water nematodes and marine nematodes of Vietnam is studied recently. At present, this investigating field on nematode biodiversity is strongly improved, in connection with creating of the new data base for the bio-monitoring assessment of water quality in watershed and wetland ecosystems of whole Vietnam. This work is a part of the Vietnam National Basic Research on Live Science Program for studying biodiversity and fauna of free-living aquatic nematodes in the mangrove forest of Vietnam during 2003-2008 years. The nematode samples were collected at the March and April 2004. In this paper, firstly three new species, Daptonema brevisetosum sp. nov, Subsphaerolaimus major sp. n. and Daptonema hirtum (Gerlach, 1951) are described.

\section{MATERIAL AND METHODS}

Samples are done from a boat using a Polar grab. In each station one grab is collected with three replicated for nematode analysis. All samples are fixed in hot formalin $10 \%$. The nematodes are extracted by LUDOX-TM 50 solution with centrifugation method and gradually transferred to anhydrous glycerin and finally mounted into permanent glass slides.

\section{Abbreviation used in the text:}

L. total body length $(\mu \mathrm{m})$; a. body length divided by maximum body width; b. body length divided by pharengeal length; c. body length divided by tail length; c'. tail length measuring anal or cloacal diameter; V. relation of distance from anterior body end to vulva for body length at per cent.

\section{DESCRIPTION}

\section{Family Xyalidae Chitwood, 1951}

\section{Daptonema brevisetosum sp. nov (fig. 1)}

Measurements: table 1.

Female: Body rather thick and medium size. Cuticle annulated, comparatively thick. Thickness of cuticle $4.5-5.5 \mu \mathrm{m}$ at middle of body. Somatic setae short, rare, 6.5-7.0 $\mu \mathrm{m}$ long. Anterior body end narrowed. Labial region isolated from the rest of body. Inner labial sensillae in shape of small, badly visible papillae. Six outer labial and four cephalic sensillae in shape of short setae and united in almost one circle. Its length about $15 \%$ of labial region width. Amphidial fovea circular and occupying $20-25 \%$ of corresponding body diameter. Amphidial fovea situated at distance 
10-11 $\mu \mathrm{m}$ from anterior body end (0.5-0.6 labial region width). Stoma small, funnel-shaped. Cervical setae present. Oesophagus muscular, cylindrical, slightly widened at its posterior end. Cardia conical, muscular, surrounded with intestinal tissue. Renette, its canal and excretory pore not observed. Rectum length shorter than anal body diameter.

Female gonad single, anterior, outstretched, situated entirely to the left of the intestine.
Vagina comparatively short, bent to anterior body end. Uterus spacious, contain numerous small spermatozoa. No postvulval sac. Two or three small vulval glands present. Vulval screscent-shaped, situated posterior to midbody; its lips not cuticularized and not protruded. Tail slender, elongate-conical, gradually narrowing. Caudal setae short and rare. Subterminal setae 13-15 $\mu \mathrm{m}$ long. Caudal glands and spinneret well developed.

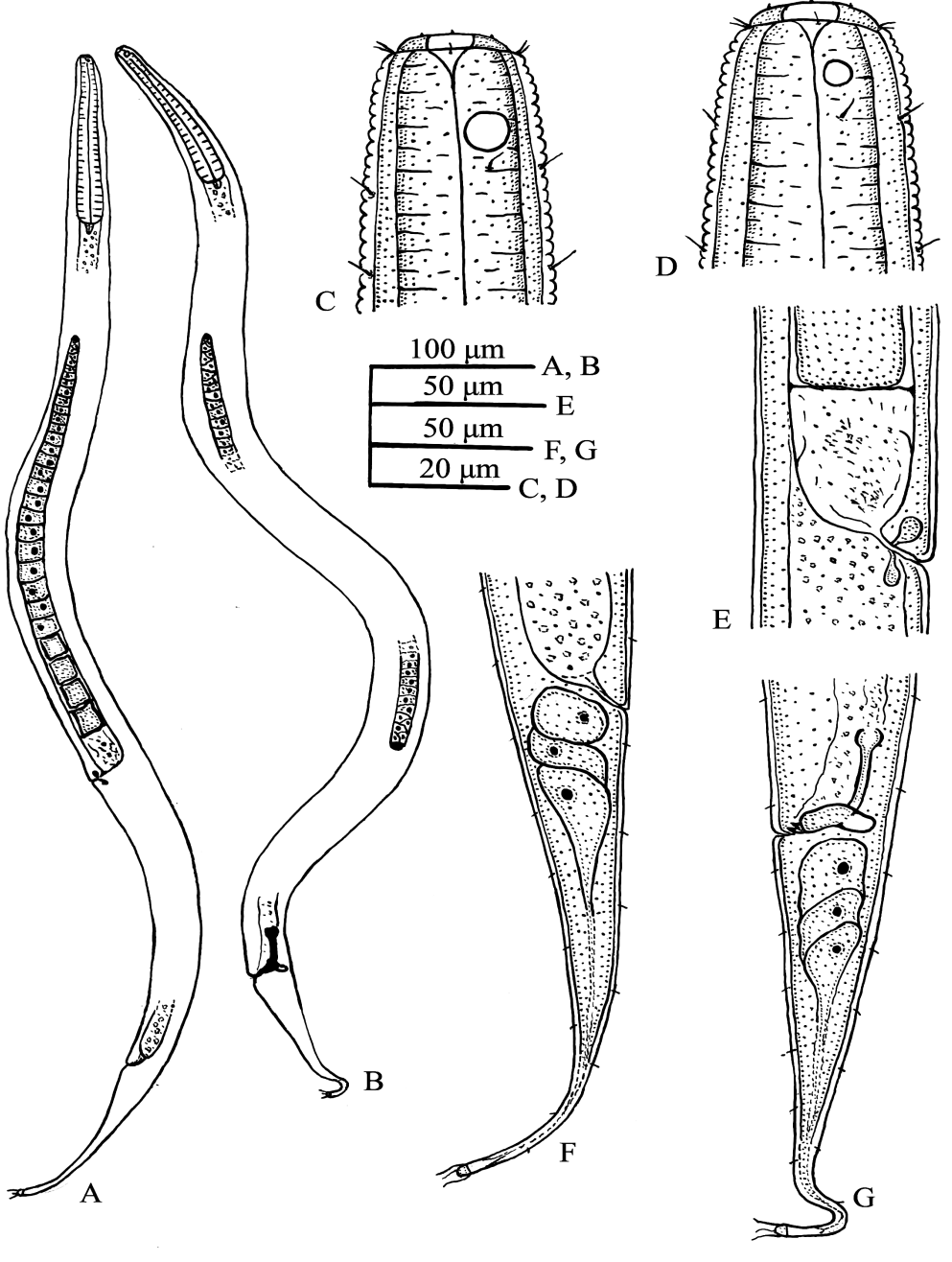

Figure 1. Daptonema brevisetosum sp. nov.

A. Entire female; B. Entire male; C. Head of male; D. Head of female; E. Vulva region; F. Tail of female; G. Tail of male.

Male: similar to females in general morphology. Cuticle annulated, comparatively thick. Somatic setae short, rare. Anterior body end narrowed. Labial region isolated from the rest of body. Inner labial sensillae in shape of small, badly visible papillae. Labial and cephalic sensillae in shape of short setae and united in almost one circle. Its length $15 \%$ of labial region width. Amphidial fovea circular and occupying $30 \%$ of corresponding body 
diameter. Amphidial fovea situated at distance $11 \mu \mathrm{m}$ from anterior body end (0.5 labial region width). Stoma small, funnel-shaped. Cervical setae present, $6.5 \mu \mathrm{m}$ long. Oesophagus muscular, cylinderoid, slightly widened at its posterior end. Renette, its canal and excretory pore not observed. Testes paired, opposed. Anterior testis outstretched, situated to the left of the intestine; posterior testis reflexed, situated to the right of the intestine. Spicules comparatively small, archly bent in the distal half, distal end acute, bifurcated. Proximal end cephalated. Spicules 1.3 times as long as cloacal body diameter. Gubernaculum comparatively massive, with dorso-caudal apophysis. Supplement absent. Tail slender, elongateconical, gradually narrowing. Caudal setae short and rare. Subterminal setae $15 \mu \mathrm{m}$ long. Caudal glands and spinneret well developed.
Type locality and habitat: Mekong River Estuary. Shore line, mangrove. Depth of waters 1.5-4.0 m, fine silt, salinity $18-24 \%$.

Type material: holotype male on slide number 44/III and paratypes $3 \circ 9$ deposited at the nematode collection of the Institute of Inland Waters Biology, Borok, Russia.

Differencial diagnosis: the new species resembles to Daptonema setosum (Bỹtschli, 1874), but differs from it by having relatively shorter outer labial setae (15\% vs $50-70 \%$ of labial region diameter in $D$. setosum), shorter spicules $(49 \mu \mathrm{m}$ long $v s$ 61-64 $\mu \mathrm{m}$ long in $D$. setosum) and shorter cervical and somatic setae (Bütschli, 1874; Bresslau et Sch. Stekhoven, 1940).

Etymology: the species name means "with short setae".

Table 1

Measurements of Daptonema brevisetosum sp. nov. (all measurements in $\mu \mathrm{m}$, exept ratio)

\begin{tabular}{|c|c|c|c|}
\hline \multirow[b]{2}{*}{ Characteristics } & \multirow[b]{2}{*}{ Holotype } & \multicolumn{2}{|c|}{ Paratypes $\mathbf{3}+q$} \\
\hline & & Range & Mean \\
\hline $\mathrm{L}$ & 1140 & $1247-1286$ & 1262 \\
\hline $\mathrm{a}$ & 22 & $18-21$ & 19 \\
\hline $\mathrm{b}$ & 7.3 & $7.3-7.8$ & 7.6 \\
\hline $\mathrm{c}$ & 7.4 & $6.6-7.1$ & 6.7 \\
\hline$c^{\prime}$ & 3.4 & $4.3-4.8$ & 4.6 \\
\hline $\mathrm{V}$ & --- & $60.0-61.6$ & 61.0 \\
\hline Labial region width & 20 & 20 & 20 \\
\hline Cephalic setae length & 3.0 & 3.0 & 3.0 \\
\hline Anterior body end to amphids fovea & 11 & $10-11$ & 11 \\
\hline Oesophagus length & 157 & $161-171$ & 167 \\
\hline Posterior end of oesophagus to vulva & --- & $596-609$ & 603 \\
\hline Vulva to anus & --- & $284-333$ & 303 \\
\hline Posterior end of oesophagus to cloaca & 829 & --- & --- \\
\hline Tail length & 154 & $182-196$ & 189 \\
\hline Spicules length (along arch) & 49 & --- & --- \\
\hline
\end{tabular}

\section{Daptonema hirtum (Gerlach, 1951) (fig. 2)}

Measurements: table 2.

Female: Body rather thick and medium size. Cuticle annulated, 3.0-4.0 $\mu \mathrm{m}$ at middle of body. Somatic setae numerous, long. These setae are especially long at the oesophagus region, its length equal 17-22 $\mu \mathrm{m}$ (1.3-1.6 labial region width). Labial region isolated from the rest of body by the redrawing. Inner labial sensillae in shape of minute obscure papillae. Six outer labial setae and four cephalic setae united in almost one circle. Outer labial setae slightly longer than cephalic setae and occupying $65-80 \%$ of labial region width. Amphidial fovea circular, 4.5-5.0 $\mu \mathrm{m}$ in 
diameter. Anterior margin of amphidial fovea situated 9-15 $\mu \mathrm{m}$ (0.8-1.1 labial region width) from anterior body end. Cheilostoma spacious, with sclerotised walls. Esophastoma small, funnel-shaped, its walls slightly sclerotised. Oesophagus slender, cylindroid, slightly widened at the posterior end. Cardia cordate, surrounded with intestinal tissue. Ventral gland, its canal and excretory pore not observed. Rectum 0.8-1.0 times as long as anal body diameter.

Female gonad single, anterior, outstretched, situated entirely to the left of the intestine. Vagina comparatively short, bent to anterior body end. Uterus spacious, contain small rounded spermatozoa. Short postvulval sac present. One egg in uterus, in size $70-87 \times 31$ $43 \mu \mathrm{m}$. Vulva posterior to middle-body, crescent-shaped; its lips not cuticularised and not protruded. Tail slender, with proximal conical and distal cylindrical portions gradually going over into one another. Tail tip slightly swollen, with subterminal setae. Caudal glands and spinneret well developed.

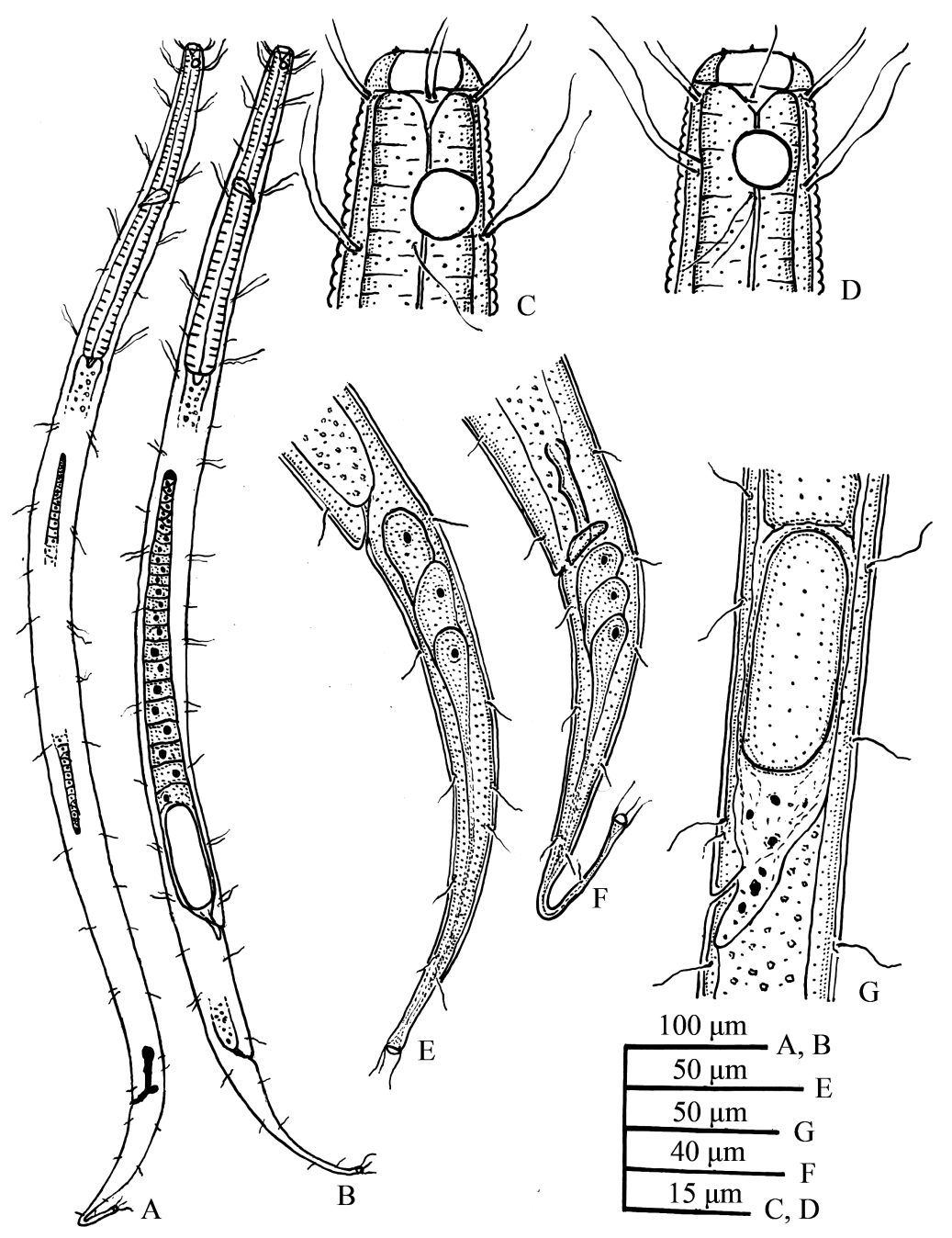

Figure 2. Daptonema hirtum (Gerlach, 1951)

A. Entire male; B. Entire female; C. Head of male; D. Head of female; E. Tail of female; F. Tail of male; G. Vulva region.

Male: similar to females in general morphology. Cuticle annulated, thick. Somatic setae present, especially long and dense at the oesophagus region. Labial region isolated from 
the rest of body by the redrawing. Inner labial sensillae in shape of minute papillae; six outer labial and six cephalic sensillae in shape of thin setae. Amphidial fovea in shape of circle, 6.5$7.5 \mu \mathrm{m}$ in diameter and situated 8-16 $\mu \mathrm{m}$ from anterior body end. Testes paired, opposed. Anterior testis outstretched, situated to the left of the intestine; posterior testis reflexed, situated to the right of the intestine. Spicules comparatively slender, arcuated, distally bifurcated and proximally widened, with shoulders and knobs. Spicules 1.3-1.5 times as long as cloacal body diameter. Gubernaculum comparatively massive, with dorso-caudal apophysis. Precloacal supplements absent. Tail slender, gradually narrowing, its posterior portion bended dorsally. Caudal setae present. Tail tip slightly swollen, with sub-terminal setae. Caudal glands and spinneret present.

Type locality and habitat: Mekong River Estuary. Shore line, mangrove forest. Depth of water 2.0-4.0 m, fine silt, salinity $18-24 \%$.

Material: 10 adult males and 10 adult females. $4 \hat{\sigma} \bar{o}$ and $2 q q$ deposited at nematode collection of the Institute of Inland Waters Biology, Borok, Russia. 6 ऽ̄ and 8 oq deposited at the nematode collection of the
Institute of Ecology and Biological Resources, Vietnam Academy of Science and Technology, Hanoi, Vietnam.

Morphological and taxonomical notes: the species Daptonema hirtum was described by German nematologist Sebastian A. Gerlach from the coast of North Sea (Gerlach, 1951). Gerlach indicated, that this new species is very close to the species Daptonema setosum (Bütschli, 1874) and differs from this letter by the shorter body, comparatively longer cephalic setae and shorter spicules. Other German nematologist. Sieverst Lorenzen found 1969 at the coast of North Sea two males of the genus Daptonema (Lorenzen, 1969) too. One male has a body length $1490 \mu \mathrm{m}$ and spicule length $60 \mu \mathrm{m}$. Second male has a body length $930 \mu \mathrm{m}$ and spicule length $40 \mu \mathrm{m}$. Sieverst Lorenzen regarded both these species to $D$. setosum and he synonymized the species Daptonema hirtum (Gerlach, 1951) with the species Daptonema setosum (Bütschli, 1874). We considered that these two males, found by Sieverst Lorenzen belong to two different species. More large species belonged to $D$. setosum and more less species belonged to $D$. hirtum. Thus, Daptonema hirtum is valid species of the genus Daptonema Cobb, 1920.

Table 2

Measurements of Daptonema hirtum (Gerlach, 1951) (all measurements in $\mu \mathrm{m}$, except ratio)

\begin{tabular}{|l|c|c|c|c|}
\hline \multirow{2}{*}{\multicolumn{1}{|c|}{ Characteristics }} & \multicolumn{2}{c|}{10 females } & \multicolumn{2}{c|}{ 10 males } \\
\cline { 2 - 5 } & range & mean & range & mean \\
\hline L & $877-1032$ & 953 & $813-949$ & 881 \\
\hline A & $25-31$ & 28 & $33-40$ & 37 \\
\hline B & $3.3-3.9$ & 3.7 & $3.6-4.1$ & 3.8 \\
\hline c & $5.8-7.7$ & 6.4 & $6.8-8.0$ & 7.3 \\
\hline c' & $5.2-7.0$ & 6.4 & $4.8-6.3$ & 5.7 \\
\hline V & $10.3-75.2$ & 73.0 & --- & --- \\
\hline Labial region width & $15-18$ & 16 & $14-17$ & 15 \\
\hline Cephalic setae length & $10-13$ & 11 & $9-12$ & 10 \\
\hline Anterior body end to amphids fovea & $9-15$ & 12 & $8-16$ & 12 \\
\hline Oesophagus length & $239-291$ & 252 & $220-256$ & 234 \\
\hline Posterior end of oesophagus to vulva & $392-497$ & 435 & --- & --- \\
\hline Vulva to anus & $99-119$ & 109 & --- & --- \\
\hline Posterior end of oesophagus to cloaca & --- & --- & $490-582$ & 526 \\
\hline Tail length & $123-169$ & 149 & $105-132$ & 121 \\
\hline Spicules length (along arch) & --- & --- & $28-30$ & 29 \\
\hline
\end{tabular}




\section{Family Sphaerolaimidae Filipjev, 1918}

\section{Subsphaerolaimus major sp. nov (fig. 3)}

Measurements: table 3.

Female: no found.

Male: Body thick and medium size. Cuticle and subcuticle smooth, without longitudinal ridges and transverse striated. Thickness of cuticle 1.5-2.0 $\mu \mathrm{m}$. Somatic setae present. Anterior body end narrowed. Labial region slightly flattened, continuing with the body outline. Inner labial sensillae in shape of small, badly visible papillae. Outer labial and cephalic sensillae in shape of short setae and united in almost one circle. Its length $38-42 \%$ of the labial region width. Subcephalic setae arranged in 8 groups, 21-38 $\mu \mathrm{m}$ long. Cheilostoma with ribs; gymnostoma narrow, with sclerotised walls; stegostoma small, funnel-shaped.
Amphidial fovea circular and occupying 35$40 \%$ of corresponding body diameter. Amphidial fovea situated at distance 13-17 $\mu \mathrm{m}$ from anterior body end (0.6-0.7 labial region width). Oesophagus muscular, cylindroid. Cardia conical, muscular, surrounded with intestinal tissue. Renetta, its canal and excretory pore not observed. Testes paired, opposed. Anterior testis outstretched, situated to the left of the intestine. Posterior testis reflexed, situated to the right intestine. Spicules comparatively thin, bended, non-cephalated, 1.1-1.2 times as long as cloacal body diameter. Gubernaculum comparatively massive, with dorso-caudal apophysis. Supplements absent. Tail slender, elongate-conical, gradually narrowing. Caudal setae short and rare. Subterminal setae 16-18 $\mu \mathrm{m}$ long. Caudal glands and spinneret present.

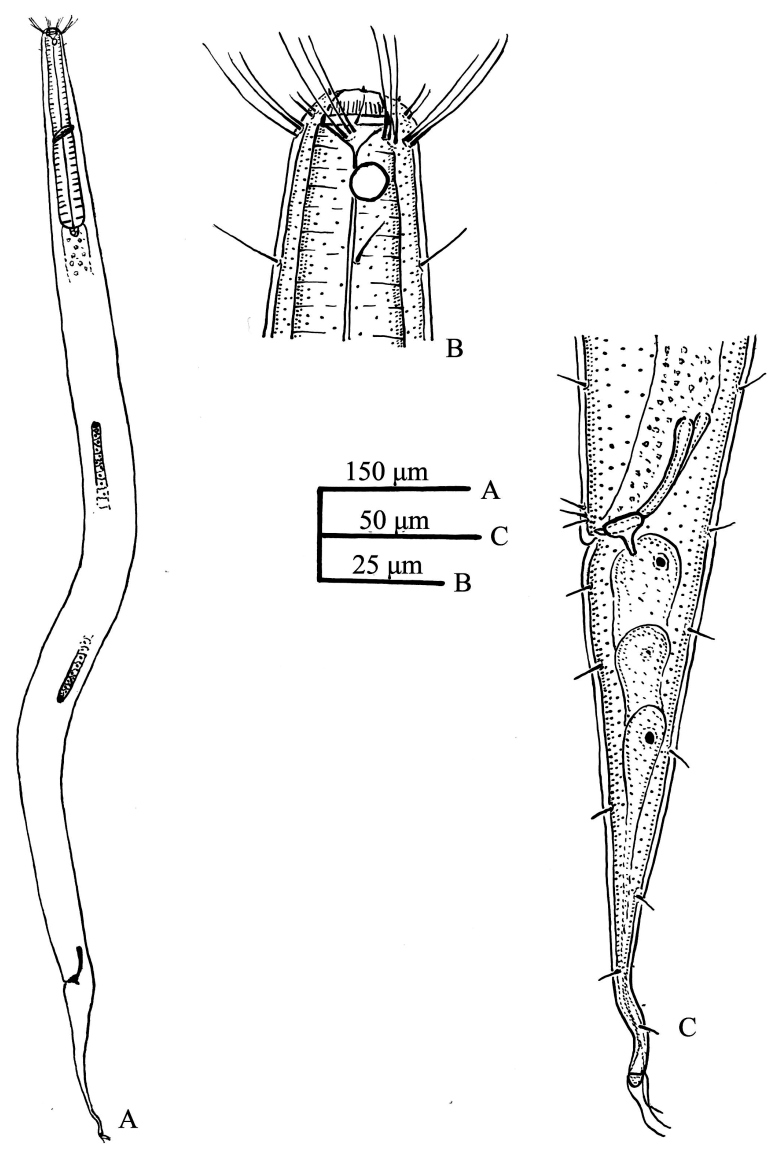

Figure 3. Subsphaerolaimus major sp. nov.

A. Entire male; B. Head of male; C. Tail of male. 
Type locality and habitat: Mekong River Estuary, shore line, mangrove. Dept of waters 2.0-4.0 m, fine silt, salinity $18-24 \%$.

Type material: holotype male on slide number 34/III deposited at the nematode collection of the Institute of Inland Waters Biology, Borok, Russia. Paratypes 4 ઈิ deposited at the nematode collection of the Institute of Ecology and Biological Resources, Vietnam Academy of Science and Texnology, Hanoi, Vietnam.

Differential diagnosis: the new species morphologically resembles to Subsphaerolaimus lamasus (Gerlach, 1956), Subsphaerolaimus gerlachi (Wieser, 1959) and Subsphaerolaimus litoralis Lorenzen, 1978. It differs from them by having longer body (in $S$. lamosus $\hat{\sigma} \mathrm{L}=0.9 \mathrm{~mm}$, in $S$. gerlachi $\hat{\sigma}$
$\mathrm{L}=0.96 \mu \mathrm{m}$, in S. lutosus $\widehat{\partial} \mathrm{L}=0.8 \mathrm{~mm}, v s \widehat{\partial}$ $\mathrm{L}=1.03-1.19 \mathrm{~mm}$ in new species), longer spicules (in S. lamasus spicules $30 \mu \mathrm{m}$ long, in S. gerlachi spicules $26 \mu \mathrm{m}$ long, in S. lutosus spicules $28 \mu \mathrm{m}$ long $v s$. spicules $46-49 \mu \mathrm{m}$ long $\mathrm{n}$ new species), shorter cephalic setae and presence of dorso-caudal apophusis of gubernaculum (Gerlach, 1956; Wieser, 1959; Lorenzen, 1978).

Etymology: the species name means "large", "big".

Acknowledgement: The study was partly supported by the Project Impact of mangrove exploitation of the Benthic ecosystem and the assessment of ecological quality objectives (IMABE) of Belgium. The authors thank the financial assistance from VLIP IMABE Project during the period of study.

Table 3

Measurements of Subsphaerolaimus major sp. nov. (all measurements in $\mu \mathrm{m}$, except ratia)

\begin{tabular}{|c|c|c|c|}
\hline \multirow{2}{*}{ Characteristics } & \multirow{2}{*}{ Holotype $\widehat{\curvearrowright}$} & \multicolumn{2}{|c|}{ Paratypes $4 \delta^{\lambda} \sigma^{\lambda}$} \\
\hline & & range & mean \\
\hline $\mathrm{L}$ & 1157 & $1032-1190$ & 1133 \\
\hline $\mathrm{a}$ & 21 & $17-21$ & 19 \\
\hline $\mathrm{b}$ & 5.7 & $5.2-5.7$ & 5.5 \\
\hline $\mathrm{c}$ & 8.2 & $6.7-8.0$ & 7.4 \\
\hline c' & 3.4 & $3.6-5.2$ & 4.0 \\
\hline Labial region width & 22 & $21-25$ & 23 \\
\hline Cephalic setae length & 8.5 & $8.5-10.0$ & 9.0 \\
\hline Anterior, body end to amphids fovea & 14.0 & $13.0-17.0$ & 15.0 \\
\hline Oesophagus length & 204 & $193-224$ & 207 \\
\hline Posterior end of oesophagus to cloaca & 812 & $679-810$ & 771 \\
\hline Tail length & 141 & $141-176$ & 155 \\
\hline Spicules length (along arch) & 47 & $46-49$ & 48 \\
\hline
\end{tabular}

\section{REFERENCES}

1. Bresslau E., J.H. Schuurmans Stekhoven, 1940: Bruxelles (Musee Hist. Nat): 1-74.

2. Bütschli O., 1874: Abh. Senckend. Naturforsch. Ges., 9: 239-292.

3. Gerlach S. A., 1951: Zool. Jb. (Syst.), Bd. 80: $379-406$.
4. Gerlach S. A., 1956: Bolm Inst. Oceanogr. S. Paulo, 5: 3-69.

5. Lorenzen S. 1969: Veröff. Inst. Meeresfosch. Bremerh., Bd., 10: 31-48.

6. Lorenzen S., 1978: Zool. Anz., Bd., 200: 53-78.

7. Wieser W., 1959: University of Washington Press. 


\title{
BA LOÀI TUYẾN TRÙNG MOMHYSTERID MỚI (NEMATODA, MONHYSTERIDA) Ở RỪNG NGậP MặN CỬA SÔNG MÊ CÔNG, VIỆT NAM
}

\author{
NGUYỄN VŨ THANH, VLADIMIR G. GAGARIN
}

\section{TÓM TÁ́T}

Mô tả ba loài loài tuyến trùng biển sống tự do thuộc bộ Monhysterida tại rừng ngập mặn ở cửa sông Mê Công, Việt Nam.

Loài mới Daptonema brevisetosum sp. nov. về hình thái học tương đối giống loài Daptonema setosum (Bütschli, 1874), song khác biệt với loài trên bởi có các lông cứng vòng ngoài cùng trên đầu ngắn hơn (15\% so với $50-70 \%$ chiều rộng vùng môi ở $D$. setosum), gai sinh dục cũng ngắn hơn (49 $\mu \mathrm{m}$ so với 61-64 $\mu \mathrm{m}$ ở loài D. setosum), ngoài ra còn khác biệt bởi các lông dinh dưỡng và lông vùng cổ cũng ngắn hơn.

Loài mới Subsphaerolaimus major sp. nov. tương đối giống với loài Subsphaerolaimus lamasus (Gerlach, 1956), Subsphaerolaimus gerlachi (Wieser, 1959) và Subsphaerolaimus litoralis Lorenzen, 1978, song khác biệt với các loài nói trên bởi có cơ thể dài hơn $(\mathrm{L}=1,03-1,19 \mathrm{~mm}$, so với $S$. lamosus $\mathrm{L}=0,9 \mathrm{~mm} ; S$. gerlachi $\mathrm{L}=0,96 \mu \mathrm{m}$ và ở $S$. lutosus $\mathrm{L}=0,8 \mathrm{~mm}$ ); gai sinh dục dài hơn (ở loài mới gai sinh dục 46-49 $\mu \mathrm{m}$; ở 3 loài trên, gai sinh dục $=26-30 \mu \mathrm{m}$ ); ngoài ra loài mới còn có thể nhận biết bởi bới hình dáng khác biệt của miếng đệm của trợ gai sinh dục, nằm gần vuông góc về phía bên lưng của đuôi.

Loài mới Daptonema hirtum được nhà khoa học Đức Sebastian Gerlach đã mô tả năm 1951 dựa trên mẫu vật mà ông thu được từ Biển Bắc, ông nhận xét rằng loài mới Daptonema hirtum về hình thái học, tương đối giống với loài đã biết trong giống Daptonema là loài $D$. setosum Bütschli, 1874, song khác biệt bởi kích thước cơ thể nhỏ hơn, lông cứng trên đầu dài hơn và gai sinh dục ngắn hơn. Năm 1969, cũng từ mẫu vật Biển Bắc nhà tuyến trùng học người Đức Sieverst Lorenzen đã gặp 2 con đực của giống Daptonema, một con có kích thước lớn $(\mathrm{L}=1490 \mu \mathrm{m}$; gai sinh dục $=60 \mu \mathrm{m})$ và con thứ hai nhỏ hơn $(930 \mu \mathrm{m}$; gai sinh dục $=40 \mu \mathrm{m})$, sau khi xem xét ông đã synonym hai loài Daptonema setosum (Bütschli, 1874) và loài Daptonema hirtum (Gerlach, 1951) thành loài Daptonema setosum (Bütschli, 1874).

Dựa vào các số đo từ mẫu vật Việt Nam cho thấy, loài Daptonema hirtum là loài hiện hữu (valid species), và hai loài $D$. Hirstum và loài $D$. Setosun là hai loài hoàn toàn khác nhau.

Ngày nhận bài: 4-3-2008 